\title{
Detection of fetal RhD gene from maternal blood
}

\author{
Maternal kandan fetal RhD tayini
}

\author{
Tuba Günel ${ }^{1}$, İbrahim Kalelioğlu², Hayri Ermiş², Kılıç Aydınlı ${ }^{3}$ \\ 'Istanbul University, Faculty of Science, Department of Molecular Biology and Genetics, Istanbul, Turkey \\ ${ }^{2}$ Istanbul University, Faculty of Medicine, Department of Obstetrics and Gynecology, Istanbul, Turkey \\ ${ }^{3}$ Istanbul University, Cerrahpasa Faculty of Medicine, Department of Obstetrics and Gynecology, Istanbul, Turkey
}

\section{Abstract}

Objective: Hemolytic disease of the newborn (HDN) is a clinic phenomenon which occurs during pregnancy due to the Rhesus (Rh) D alloimmunization between a Rh (-) pregnant woman, who has become sensitive to $\mathrm{RhD}$ antigens, and her $\mathrm{Rh}(+)$ fetus. As a result of the attack of maternal RhD antibodies on fetal RhD antigens, fetal anemia, HDN and fetal death may occur. \% 40 of Rh (-) pregnant women carry Rh (-) fetus. However, all Rh (-) pregnant women are offered anti-D Immunoglobulin (Anti-D Ig) at 28 weeks' gestation in case of fetomaternal haemorrhage, so the pregnant women carrying Rh (-) fetus are exposed to blood products unnecessarily. Although the RhD of fetus can be detected, methods used for prenatal diagnosis recently are invasive tests and they can result in abortion in a certain percentage. The discovery of circulating cell-free fetal nucleic acids in maternal plasma has opened up new possibilities for non invasive prenatal diagnosis. The aim of this study was to detect prenatal RhD by analysing the presence of the $\mathrm{RhD}$ gene of fetal DNA in maternal blood.

Material and Methods: Total free DNA was isolated from the blood of $19 \mathrm{Rh}(-)$ pregnant women, who had RhD alloimmunization with their husbands, in the 11-14 th week of their pregnancy. The existence of a gene in isolated DNA was investigated with TaqMan prob and "Realtime PCR" method by using primers belonging to exon 7 of RhD gene.

Results: Using a quantitative real-time PCR assay, the presence of RhD gene sequences was evaluated in the serum of patients at the onset of pregnancy. We have analyzed $19 \mathrm{Rh}(-)$ pregnant women. Twelve of them were Rh (-) and the rest of them were $7 \mathrm{Rh}(+)$. After birth the baby's blood groups were concordant with our results.

Conclusion: The results obtained by $\mathrm{RhD}$ primer were analysed. The possibility of detection of fetal RhD gene in maternal blood contributed to noninvasive prenatal diagnosis.

(J Turkish-German Gynecol Assoc 2010; 11: 82-5)

Key words: Fetal DNA, RhD gene, real-time PCR

Received: 2 January, 2010

Accepted: 20 April, 2010
Özet

Amaç: Yeni doğanın hemolitik hastalığı, daha önce "Rhesus" (Rh) D antijenleri ile duyarlı hale gelmiş Rh (-) anne ile Rh (+) çocuğu arasındaki RhD uyumsuzluğuna bağlı olarak hamilelik sürecinde ortaya çıkan klinik bir tablodur. Maternal RhD antikorlarının fetal RhD antijenlerini yok etmesiyle, fetusta kansızlık, yenidoğanda sarılık veya fetal ölüm gerçekleşebilir. Rh (-) gebelerin yaklaşık \% 40'ı Rh (-) fetus taşımaktadır. Buna rağmen tüm gebelere olası bir fetal kanama riskine karşı hamileliklerinin 28. haftasında anti D immünglobulin (Anti-D Ig) uygulanmakta ve $\mathrm{Rh}(-)$ fetus taşıyan gebeler gereksiz aşı ürününe maruz kalmaktadır. Doğum öncesi tanı ile fetusun RhD tayini yapılabilse de, günümüzde kullanılan doğum öncesi tanı metodları girişimsel tetkikler olup belli oranlarda gebelik kayıplarına neden olabilmektedir. Anne kanında fetusa ait nükleik asitlerin hücre dışında serbest dolaşabileceklerinin keşfi noninvazif prenatal tanı için yeni olanaklar açmıştır. Bu çalışmada da maternal kandan fetal DNA'da RhD geninin varllğına bakılarak doğum öncesi RhD tayini yapılabilmesi amaçlanmıştır.

Gereç ve Yöntemler: 11-14. gebelik haftalarında bulunan ve eşleriyle aralarında $\mathrm{RhD}$ uyumsuzluğu olan $19 \mathrm{Rh}(-)$ gebeden kan alınarak total serbest DNA izolasyonu yapılmıştır. İzole edilen DNA'larda RhD geninin ekson 7 bölgesine ait primerler kullanılarak, TaqMan prob yöntemi ile ve "Real-time PCR" aracılığıyla genin varlığı araştırılmıştır. Bulgular: "Real-time PCR" kullanılarak gebeliklerinin başında olan hastaların serumlarında RhD gen dizilerinin varlığı değerlendirildi. Analiz edilen 19 Rh (-) gebenin 12'sinin (Rh-), 7'sinin Rh (+) olduğu belirlendi. Doğum sonrasında bebeklerin kan grupları ile bizim sonuçlarımız birebir uyumlu çıkmıstır.

Sonuç: RhD primeri ile alınan sonuçlar analiz edilmiştir. Fetüse ait $\mathrm{RhD}$ geninin maternal kanda belirlenebilmesi girişimsel olmayan doğum öncesi tanı için önemli bir katkı sağlamıştır.

(J Turkish-German Gynecol Assoc 2010; 11: 82-5)

Anahtar kelimeler: Fetal DNA, RhD gen, gerçek zamanlı PZR

Geliş Tarihi: 02 Ocak $2010 \quad$ Kabul Tarihi: 20 Nisan 2010

death, fetal anemia or neonatal icterus (1). The Rhesus (Rh) blood group system is a very polymorphic system. RhD and RhCE are located in the region of p36.13-p34.3 on chromosome 1, and they are $97 \%$ homologous to each other. Each of these genes consists of 10 exones, and they contain $69 \mathrm{~kb}$ of DNA. The regions of exone 7 and exone 10 within the RhD gene are the areas of focus. In all positive results, the RhD blood group has also been found positive (2). The bi-sidal flow from the placenta during pregnancy has been presented 
in many studies (3). Free fetal DNAs stemming from the destruction of fetal cells in earlier weeks of pregnancy transport to the maternal blood via the bi-sidal flow through the placenta (4). $3 \%-6 \%$ of free DNAs in the plasma of pregnant women have been found to be fetal in origin (5). When the properties brought by the the fetal DNA as a genetic substance has been considered, many studies putting forward the assumptions of the possibility of recognizing some of the genetical diseases during pregnancy and the emphasis of the issue at prenatal diagnosis have been subject to questioning. However, as the purifying can be applied to have an access to total free DNA, the particularity that belongs to the fetus does not have to be found in the mother (the chromosomal disorders and gender) and has to be inherited by a single gene (thalassemia and cystic fibrosis) (6).

The determination of the free fetal DNA and RhD gene in maternal blood make it possible to detect the RhD sitiuation of baby via a non-invasive method. Studies put more emphasis on this area (7). Unnecessary application of Anti D Ig can be prevented for pregnant women who carry a Rh - fetus, also this results in a better follow-up of pregnant women who carry a Rh+ fetus with the detection of $\mathrm{RhD}$ genotype of fetus in maternal plasma at the first trimester of pregnancy.

Lately, widely used methods of prenatal genetic diagnosis are invasive examinations that may lead to specific rates of pregnancy loss. Therefore, prenatal diagnosis should be applied to high risk pregnant women rather than all pregnant women. Despite applying some prenatal screening methods to constitute the so-called risk group, these screening results cannot provide an accurate result (8). With the help of developing noninvasive prenatal diagnostic techniques, prenatal diagnostic methods giving certain results can be applied to all pregnant women without any screening. Therefore, the need of the invasive procodures, such as amniocentesis and chorion villus sampling to get fetal cells for the resources of fetal DNA, has to be replaced (9).

Horizons of prenatal diagnosis expand continuously, and the methods which are faster, less costly and harmful for the baby, as well as mothers are being developed in order to put into practice.

\section{Material and Methods}

$5 \mathrm{ml}$ blood was taken from each $19 \mathrm{Rh}$ (-) pregnant woman having Rh incompatibility with their husbands who came to 11-14 week controls to the Istanbul University Faculty of Medicine, Department of Gynecology and Obstetrics, and Istanbul University Cerrahpasa Medical Faculty, Department of Gynecology and Obstetrics. The day blood was taken, they were centifuged $15^{\prime}$ at $4100 \mathrm{~g}$, and saved at $-80^{\circ}$ until the day of the isolation of upper fluid. The total free DNA isolation was performed according to free DNA isolation procedures of High Pure PCR Template Preparation Kit" (Roche Applied Science Kat. No: 11796828 001). The samples that were saved at- $80^{\circ}$ were first centrifuged at $13000 \mathrm{rpm}$ for 10' and upper fluids were taken. $200 \mu \mathrm{l}$ "Binding Buffer" and $40 \mu \mathrm{l}$ "Proteinase K" were put in each sample, and they were kept at $70^{\circ}$ in a water bath for 10'. $100 \mu \mathrm{l}$ isopropanol were also added to them and the mixtures were taken to strainer eppendorf and centrifuged until all of the liquid passed to the bottom. $500 \mu \mathrm{l}$ "Inhibitor Buffer" was added to eppendorfs and centrifuged. Two cetrifuges were then also formed by adding $500 \mu \mathrm{l}$ "Wash Buffer" each time. Next, $50 \mu \mathrm{l}$ "Elution Buffer" was added to strainer eppendorfs, the sub- tube which had free DNA after centrifugation was taken to $-20^{\circ}$ until the day of "Real Time PCR" would be conducted. With the content on Table 1 and at the conditions on Table 2, "Real Time PCR" for gene detection was perfomed by using the specific primers (5'-CTC CAT CAT GGG CTA CAA-3', 5'-CCG GCT CCG ACG GTA TC-3') for region exon 7 which belongs to RhD and TaqMan prob (5'-FAM AGC AGC ACA ATG TAG ATG ATC TCT CCA TAMRA-3'); FAM [6 carboxyfluorescein] and TAMRA [6 carboxytetrametthylrhodamine] were the fluorescent reporter dye and quencher dye, respectively. The tubes which contained $\mathrm{RhD}$ genes were used for positive control, and the tubes that were known not to contain $\mathrm{RhD}$ gene were used for negative control. The tubes containing the NTC (PCR mixture without DNA) reaction mixture was used for the determination of contamination.

\section{Results}

The total DNA of 19 pregnant women that were known to be Rh-, was analyzed with positive and negative controls by NTC "TaqMan prob" method, negative control, NTC. 12 samples were found to be $\mathrm{RhD}(-)$ and positive control, and 7 samples were found to be $\mathrm{RhD}(+)$ (Table 3 ).

\section{Discussion}

After the discovery of free fetal DNA (10), tremendous progress has been made in prenatal diagnosis. The detection of prenatal fetal gender, and fetuses having single gene disorders that are paternally inherited and hemolytic diseases are actualized by

Table 1. Components of amplification mixture

\begin{tabular}{|l|c|c|}
\hline Component & Volume $(\mu \mathrm{l})$ & Final amount \\
\hline TaqMan Probes & 0.6 & $25 \mathrm{nM}$ \\
\hline Forward Primer & 3 & $300 \mathrm{nM}$ \\
\hline Reverse Primer & 3 & $300 \mathrm{nM}$ \\
\hline $\mathrm{dH}_{2} \mathrm{O}$ & 13.4 & - \\
\hline Template DNA & 5 & $20 \mathrm{ng}$ \\
\hline PCR Reaction Buffer & 25 & - \\
\hline
\end{tabular}

Table 2. Cycling parameters

\begin{tabular}{|l|c|cc|}
\hline & Segment $\mathbf{1}$ & \multicolumn{2}{|c|}{ Segment 2 } \\
\hline Temperature $\left({ }^{\circ} \mathrm{C}\right)$ & 95 & 95 & 60 \\
\hline Time & $10 \mathrm{~min}$ & $15 \mathrm{~min}$ & $1 \mathrm{~min}$ \\
\hline Cycles & 1 & \multicolumn{2}{|c|}{50} \\
\hline
\end{tabular}


Table 3. Results of RhD genotyping of fetuses of $\mathrm{RhD}$ negative women with the use of RhD Real-time PCR assay and serologic $\mathrm{RhD}$ typing of the newborns

\begin{tabular}{|c|c|c|c|}
\hline $\begin{array}{l}\text { Samples } \\
\text { values }\end{array}$ & $\begin{array}{c}\mathrm{CT} \\
\text { results }\end{array}$ & $\begin{array}{l}\text { Real-Time PCR } \\
\text { Rh phenotypes }\end{array}$ & Newborn \\
\hline $\begin{array}{c}\text { NTC } \\
\text { (No template } \\
\text { control) }\end{array}$ & - & - & - \\
\hline Positive control & 25.63 & $\mathrm{Rh}(+)$ & $\mathrm{Rh}(+)$ \\
\hline Negative control & - & Rh (-) & Rh (-) \\
\hline 1 & - & $\mathrm{Rh}(-)$ & $\mathrm{Rh}(-)$ \\
\hline 2 & - & Rh (-) & Rh (-) \\
\hline 3 & - & Rh (-) & Rh (-) \\
\hline 4 & - & Rh (-) & $\mathrm{Rh}(-)$ \\
\hline 5 & 34.83 & $\operatorname{Rh}(+)$ & $\mathrm{Rh}(+)$ \\
\hline 6 & - & Rh (-) & Rh (-) \\
\hline 7 & 34.25 & Rh (+) & $\mathrm{Rh}(+)$ \\
\hline 8 & - & Rh (-) & Rh (-) \\
\hline 9 & 34.65 & $\operatorname{Rh}(+)$ & $\mathrm{Rh}(+)$ \\
\hline 10 & 35.52 & Rh (+) & $\mathrm{Rh}(+)$ \\
\hline 11 & 32.31 & $\mathrm{Rh}(+)$ & $\mathrm{Rh}(+)$ \\
\hline 12 & 34.56 & Rh (+) & $\mathrm{Rh}(+)$ \\
\hline 13 & - & $\mathrm{Rh}(-)$ & Rh (-) \\
\hline 14 & - & Rh (-) & Rh (-) \\
\hline 15 & 34.19 & $\mathrm{Rh}(+)$ & $\mathrm{Rh}(+)$ \\
\hline 16 & - & Rh (-) & Rh (-) \\
\hline 17 & - & Rh (-) & Rh (-) \\
\hline 18 & - & Rh (-) & Rh (-) \\
\hline 19 & - & $\mathrm{Rh}(-)$ & $\mathrm{Rh}(-)$ \\
\hline
\end{tabular}

the researches conducted during this period. The accuracy rates between $98 \%-100 \%$ of researches shows that recently, fetal RhD detection can be applied routinely to Rh (-) women, and the use of human anti -D can be significantly reduced (9). Fetal DNA can be identified from the 5th week of pregnancy in maternal blood and is rapidly destroyed immediately after birth. However, only 3\%-6\% of total DNA in maternal blood is welded fetal origin (11). Genes inherited from the mother are pressured by excessive quantities of free maternal DNA. This situation prevents only prenatal diagnosis of X-linked or recessive inherited diseases. The sensitivity of the studies that have been recently carried out by the devoleped PCR techniques has been increased, but the greatest difficulty encountered is the isolation of pure and high scale fetal DNA. By doing this isolation, the need of invasive procedures, such as amniocentesis will largely be eliminated (9).

The complete disappearance of invasive procedures can be made possible by putting studies into practice that begin with the discovery of fetal mRNA transcripts. The discovery can open a new array in the field of detection of chromosomal disorders, which cannot be determined by free DNA and follow-up fetal maturing (9).

In the study, the reality of results were confirmed by postnatal tests and after birth the baby's RhD blood groups were concordant with the results. There have been no nonunderstood amplifications and contaminations found in the samples. Only 7 of the 19 pregnant women that are known as Rh (-) samples have been found with RhD gene. $40 \%$ of Rh (-) pregnant women were identified to have Rh (-) fetus (12). The low number of samples that was analyzed indicates higher results than expected. The higher rate expected from the society can be related to the higher number of heterozygote fathers than supposed and this can be changed by increasing the number of samples. The costs of use of unnecessary vacine products can be higher according to our results (13).

There are $\mathrm{RhD}$ variants in society that make no expression or low expression, and this causes false negative results. The RhD $\Psi$ pseudogene, which causes RhD negative phenotype in the African black population is exposed to too many mutations. As a result, it has variants that make low expression, which may in turn lead to false negative and false positive results (14).

The concordance of the results of "Real-Time PCR" analysis of region exon 7 belonging to $\mathrm{RhD}$ gene after the detection of fetal DNA from maternal plasma and the RhD blood group results of babies confirm the high sensitivity and reliability of the method. The study indicates toe need to work on the regions of exon 7 and exon10 together for more sensitive and reliable applications $(14,15)$.

\section{Conflict of interest}

None declared

\section{References}

1. Avent ND, Reid ME. The rh blood group system: a review. Blood 2000; 95: 375-87.

2. Huang CH. 1998, The human Rh50 glycoprotein gene-structural organization and associated splicing defect resulting in Rhnull disease, Journal of Biological Chemistry, 1998; 273: 2207-13.

3. van der Schoot C, Hahn S, Chitty L. Non-invasive prenatal diagnosis and determination of fetal Rh status. Seminars in Fetal and Neonatal Medicine 2008; 13: 63-8

4. Gonzales-Gonzales C, Garcia-Hoyos M, Trujillo-Tiebas MJ, LordaSanchez I, de Alba MR, Infantes F, et al. Application of fetal dna detection in maternal plasma: A prenatal diagnosis unit experience. Journal of Histochemistry and Cytochemistry 2005; 53: 307-14.

5. Daniels G, Finning K, Martin P, Massey E. Noninvasive prenatal diagnosis of fetal blood group phenotypes: current practice and future prospects, Prenat Diagn. 2008; 29: 101-7.

6. Lun FM, Tsui NB, Chan KC, Leung TY, Lau TK, Charoenkwan P. Noninvasive prenatal diagnosis of monogenic diseases by digital size selection and relative mutation dosage on dna in maternal plasma, Proc Natl Acad Sci U S A. 2008; 105: 19920-5.

7. Purwosunu Y, Sekizawa A, Okai T. Detection and quantification of fetal DNA in maternal plasma by using LightCycler technology. Methods Mol Biol. 2008; 444: 231-8. 
8. Lo YM. Fetal RhD genotyping from maternal plasma. Ann.Med. 1999; 31: 308-12.

9. Hahn S, Chitty L. Noninvasive prenatal diagnosis: current practice and future perspectives. Current Opinion in Obstetrics and Gynecology. 2008; 3: 150-7.

10. Lo YM, Corbetta N, Chamberlain PF, Rai V, Sargent IL, Redman CW, et al. Presence of fetal dna in maternal plasma and serum. Lancet. 1997; 350: 485-7.

11. Freeman K, Szczepura A, Osipenko L. Non-invasive fetal rhd genotyping tests: a systematic review of the quality of reporting of diagnostic accuracy in published studies, Eur J Obstet Gynecol. 2008; 142: 91-8.

12. Finning F, Martin P, Summers J, Massey E, Poole G, Daniels G. Effect of high throughput rhd typing of fetal dna in maternal plasma on use of anti-rhd immunoglobulin in rhd negative pregnant women: prospective feasibility study. Br Med J. 2008; 336: 816-8.

13. Jorgez CJ, Dang D, Simpson J, Lewis DE, Bischoof Fz. Quantity versus quality:optimal methods for cell-free dna isolation from plasma of pregnant woman. Genetics in Medicine. 2006; 8: 615-9.

14. Rouillac-Le Sciellour C, Puillandre P, Gillot R, Baulard C, Metral S, et al. Mol. Diagn. 2004; 8: 23-31. Large-scale pre-diagnosis study of fetal RHD genotyping by PCR on plasma DNA from RhD-negative pregnant women. Mol. Diagn. 2004; 8: 23-31.

15. Rouillac-Le, Sciellour C, serazin V, Brossard Y, Oudin O, Le Van Kim $\mathrm{C}$, et al. Noninvasive fetal RHD genotyping from maternal plasma use of new developed free DNA fetal kit RHD ${ }^{\circledR}$. Transfusion. 2007; 14: 572-7. 